\title{
REVIEW
}

\section{Cytokine disturbances in systemic lupus erythematosus}

\author{
Noam Jacob and William Stohl*
}

\begin{abstract}
The pathogenesis of systemic lupus erythematosus

(SLE) is complex, and the resulting disease

manifestations are heterogeneous. Cytokine

dysregulation is pervasive, and their protein and gene

expression profiles may serve as markers of disease

activity and severity. Importantly, biologic agents

that target specific cytokines may represent novel

therapies for SLE. Four cytokines (IL-6, TNFa, IFNa, and

BLyS) are being evaluated as therapeutic targets in

SLE. The present review will examine the roles of each

of these cytokines in murine and human SLE, and will

summarize results from clinical trials of agents that

target these cytokines.
\end{abstract}

\section{Introduction}

Cytokines collectively play key roles in the regulation of systemic inflammation, local tissue damage, and immunomodulation. Not surprisingly, cytokines often play direct roles in disease pathogenesis, including that of systemic lupus erythematosus (SLE). To the chagrin of both investigator and practitioner, the effects of cytokines are pleiotropic and include both synergistic and antagonistic effects on other cytokines - thereby introducing tremendous complexity that has often led to diametrically opposing conclusions in different studies. In the present review, we focus on four cytokines that have received great attention either as candidate biomarkers for disease activity and/or as candidate targets of novel biologic agents.

\section{Interleukin-6}

\section{General biology of IL-6}

IL-6 is a pleiotropic $26 \mathrm{kDa}$ protein produced by a panoply of cell types, and affects the function of an equally broad

*Correspondence: stohl@usc.edu

Division of Rheumatology, Department of Medicine, University of Southern California Keck School of Medicine, 2011 Zonal Ave, HMR 711, Los Angeles, CA 90033, USA spectrum of cell types. Of greatest relevance to SLE is the ability of IL- 6 to promote activation and/or differentiation of cells central to the development of systemic autoimmunity and the attendant pathologic inflammatory responses, including $\mathrm{T}$ cells, $\mathrm{B}$ cells, macrophages, and neutrophils [1].

IL-6 signal transduction occurs via coordinated interactions between the $80 \mathrm{kDa}$ IL- 6 binding chain (IL-6 receptor (IL-6R), IL-6R $\alpha$ chain, CD126) and the $130 \mathrm{kDa}$ signal transducing chain (gp130, IL-6R $\beta$ chain, CD130). IL-6 can bind to membrane IL-6R, thereby inducing homodimerization of gp130 and leading to activation of gp130-associated JAK1 and tyrosine phosphorylation of gp130. Alternatively (and not mutually exclusively), IL-6R can be enzymatically cleaved from the cell surface, thereby producing soluble IL-6R. Soluble IL-6R can then bind circulating IL-6 and form IL-6/IL-6R complexes that act on cells expressing gp130 [1].

\section{IL-6 in murine systemic lupus erythematosus}

Studies in multiple murine SLE models point to an essential role for the IL-6 pathway in SLE. Genetic deficiency of IL-6 in MRL/lpr mice delays disease development, reduces $\mathrm{CD}^{+}$and $\mathrm{CD}^{+}$T-cell numbers, decreases glomerular IgG and $\mathrm{C} 3$ deposition, downregulates renal parenchymal vascular cell adhesion molecule-1 (VCAM-1) expression, and diminishes kidney macrophage infiltration [2]. This last effect may be especially important, in as much as a close association between activated renal macrophages and disease has been documented in (NZB x NZW)F1 (BWF) mice [3].

Additional important observations have been made with BWF mice. Exogenous IL-6 increases IgG anti-DNA autoantibody production by $\mathrm{B}$ cells isolated from clinically affected BWF mice, whereas neutralization of IL-6 via either addition of an anti-IL- $6 \mathrm{mAb}$ or macrophage depletion decreases production of such autoantibodies [4-6]. Building on these ex vivo findings, administration of human IL-6 to 6-month-old female BWF mice promoted accelerated membranoproliferative glomerulonephritis associated with marked upregulation of mesangial MHC class II antigens and glomerular intercellular adhesion molecule-1 (ICAM-1) expression. 
Treatment with cyclosporin inhibited the development of glomerulonephritis, distinguishing the effects of IL-6 on systemic inflammation from its direct effect on renal mesangial cells [7]. More impressive were the significant decreases in mortality, progression of proteinuria, and anti-dsDNA antibody levels in BWF mice chronically treated from 3 months of age with anti-IL- 6 mAb or antiIL6 receptor antibody $[8,9]$.

IL-6 is also associated with SLE in other murine SLE models. In pristine-induced SLE, renal disease was milder, and high levels of IgG anti-single-strand DNA, anti-dsDNA, and anti-chromatin antibodies were absent in IL-6-deficient mice [10]. In JunB ${ }^{\Delta e p}$ mice, development of an SLE-like phenotype (including skin lesions and immune complex glomerulonephritis) was linked to increased epidermal IL-6 secretion that arose from the specific loss of epidermal JunB. Intercrosses with IL-6deficient mice abrogated the SLE phenotype [11].

\section{IL-6 in human systemic lupus erythematosus}

As in murine SLE, serum levels of IL- 6 are elevated in human SLE and have correlated with disease activity or anti-dsDNA levels in some studies [12-14]. The increased frequency of IL-6-producing peripheral blood mononuclear cells correlates with disease severity/activity and treatment response $[15,16]$. Of note, SLE B cells express IL-6R spontaneously and produce great amounts of IL-6 $[17,18]$. Moreover, autoreactive T-cell clones from SLE patients also produce large amounts of IL-6, and thereby promote B-cell activation and autoantibody production [19]. Indeed, the copious spontaneous production of immunoglobulin by SLE B cells can be enhanced by exogenous IL- 6 and diminished by neutralizing antibodies to IL-6 [13].

Aside from its systemic effects, IL-6 is closely linked with specific disease manifestations. Elevated cerebral spinal fluid levels of IL-6 are found in SLE patients with psychosis and may afford an effective measure of its diagnosis [20]. In SLE nephritis patients, urinary levels of IL-6 are elevated, correlate with titers of anti-dsDNA antibodies, and decrease following treatment [14,21]. Local expression of IL-6 was documented in kidney tissue of SLE nephritis patients [22], arising at least in part from mesangial cells [23].

\section{Therapeutic blockade of IL- 6 in systemic lupus erythematosus}

Given the considerable evidence pointing to a contributory role for IL-6 in SLE pathogenesis, the a priori likelihood that therapeutic targeting of this pathway in SLE will be efficacious is high. Tocilizumab, a mouse-human chimeric anti-human anti-IL-6R mAb, is already US Food and Drug Administration approved for the treatment of patients with rheumatoid arthritis. Tocilizumab effectively inhibits IL-6 signal transduction by its ability to bind both mIL-6R (preventing IL-6 binding to cell-surface mIL-6R/gp130 complex) and sIL-6R (preventing formation of IL-6/sIL-6R complex, which could bind to cell-surface gp130).

Although initial results suggest that tocilizumab can control SLE disease activity, an increased risk of infections may limit its ultimate clinical utility. In an open-label phase I dosage-escalation study (Table 1), 16 patients with mild to moderate disease activity (presence of chronic glomerulonephritis or extrarenal SLE Disease Activity Index - SELENA modification score of 3 to 10) received one of three doses of tocilizumab $(2,4$, or $8 \mathrm{mg} /$ $\mathrm{kg}$ ) every other week for 12 weeks [24]. Disease activity showed improvement, with a decrease of $\geq 4$ points in activity scores for eight of 15 evaluable patients. Additionally, arthritis improved in all seven patients who had arthritis at baseline, and completely resolved in four of them. There were also significant decreases in the frequency of circulating plasma cells and in levels of antidsDNA antibodies. Tocilizumab also led to a similar decline in levels of $\mathrm{C} 3$ and the complement activation products, iC3b and C5b-9 (terminal activation complex). Tocilizumab treatment led to dose-related decreases in the absolute neutrophil count, however, with two patients experiencing severe neutropenia (absolute neutrophil count of 500 to $1,000 / \mu \mathrm{l})$. The decline in neutrophil counts probably had clinical consequences - 16 infections developed in 11 patients, 10 of whom required systemic antibiotics or antivirals. Additional studies are clearly needed before tocilizumab or other IL- 6 antagonists can be considered viable therapeutics in human SLE.

\section{Tumor necrosis factor alpha \\ General biology of TNFa}

TNF $\alpha$ is expressed as a $26 \mathrm{kDa}$ transmembrane protein that can be cleaved by TNF $\alpha$-converting enzyme to release a $17 \mathrm{kDa}$ soluble protein [25]. Like IL-6, TNF $\alpha$ is produced by a variety of cells, including activated macrophages and monocytes as well as B cells, T cells, keratinocytes, renal cells, and fibroblasts.

Depending upon the conditions, TNF $\alpha$ can trigger either proinflammatory or anti-inflammatory pathways by engaging one or both of two distinct transmembrane receptors: the type I, p55 tumor necrosis factor receptor (TNFR1), and the type II, p75 TNFR (TNFR2) [26]. TNFR1 may trigger apoptotic and anti-inflammatory signals through Fas-associated death domain (FADD) and activation of the caspase cascade. Conversely, it may also trigger anti-apoptotic and proinflammatory responses through recruitment of TNF receptor-associated factor 2 (TRAF-2), which activates NF- $\mathrm{kB}$, c-Jun NH2terminal kinase (JNK), and mitogen-activated protein (MAP) kinase. Binding of TNFa to TNFR2 also leads to 
Table 1. Cytokine-targeting agents and their clinical trials in SLE

\begin{tabular}{lllr}
\hline Cytokine target & Therapeutic agent & Stage of clinical trial & References \\
\hline IL-6 & Tocilizumab & Phase I & [24] \\
TNFa & Infliximab, etanercept & Phase I; phase II and III trials terminated prematurely & {$[53-55]$} \\
IFNa & Sifalimumab (MEDI-545), rontalizumab (rhuMab) & Phase I; phase II ongoing & [102,103] \\
BLyS & Belimumab & Phase III completed & {$[115-121]$} \\
& A-623 & Phase I; phase II suspended/restarted & {$[123]$} \\
& LY2127399 & Phase III planned & {$[125]$} \\
BLyS and APRIL & Atacicept & Phase II/III initiated & {$[122]$} \\
\hline
\end{tabular}

recruitment of TRAF2 and promotes proinflammatory responses. The TNF/TNFR system can thus serve dually both as a potent proinflammatory mediator and as a key immune modulator as a function of the immunological setting $[25,26]$.

\section{TNFa in murine systemic lupus erythematosus}

Several studies point to a pathogenic role for TNFa in murine SLE. TNFo expression is increased in the sera and kidneys of MRL/lpr mice and correlates with disease activity $[27,28]$. Indeed, TNF antagonism/inhibition in such mice has clinical benefit. Furthermore, in C3H.SW mice with induced SLE, treatment with anti-TNFo mAb results in decreased development of anti-DNA antibodies, proteinuria, and glomerular immune-complex deposition $[29,30]$.

In sharp contrast, the administration of recombinant TNF $\alpha$ or TNF $\alpha$-inducing agents to BWF mice is clearly beneficial [31-33]. Moreover, TNF $\alpha$ deficiency in other SLE mice has resulted in disease induction/exacerbation. Autoimmunity and fatal SLE nephritis develop in NZB mice when crossed with TNF $\alpha$-deficient mice [34]. Similarly, TNF $\alpha$ deficiency in mice bearing a mixed B6/129 genetic background $\left(\mathrm{H}-2^{\mathrm{b} / \mathrm{b}}\right)$ develop $\operatorname{IgG}_{2 \mathrm{~b}}$ and $\mathrm{IgG}_{3}$ anti-DNA antibodies, glomerular IgG deposition, and alterations in glomerular structure resembling SLE nephritis [35].

These often conflicting effects of TNF $\alpha$ in different murine SLE models underscore this cytokine's dual proinflammatory and immunoregulatory roles. These conflicting effects are also disease stage specific and may reflect the cell type expressing the receptors as well as differential expression of the receptors themselves by a given cell type. Although the underlying molecular and cellular mechanisms remain largely enigmatic, at least part of TNF's functional duality might segregate at the level of the two TNF $\alpha$ receptors $[35,36]$. Indeed, in antiGBM antibody-induced glomerulonephritis, TNFR2 deficiency is protective, whereas TNFR1-deficient mice develop proteinuria and renal pathology similar to those in wild-type controls [37]. In addition, TNFR1 deficiency greatly accelerates lymphoadenopathy, autoantibody production, and mortality in C57BL/6-lpr mice [38]. In NZM2328 mice singly deficient in one TNFR, however, signaling through the other receptor can compensate and permit persistence of the wild-type clinical and pathological phenotypes. Deletion of both receptors, with complete abrogation of TNF $\alpha$ signaling, results in significantly accelerated disease [39].

\section{TNFa in human systemic lupus erythematosus}

As in animal models, the evidence has been conflicting regarding the role of TNF $\alpha$ in human SLE. Some studies have shown that serum TNF $\alpha$ levels are elevated in SLE patients and correlate with disease activity [40,41]. Other studies, however, have shown otherwise. One study demonstrated that elevated TNF $\alpha$ plasma levels do not correlate with SLE disease activity, and another study showed that TNF $\alpha$ levels were actually higher in patients with inactive disease, suggesting a protective role for TNF $\alpha$ in SLE $[42,43]$. Differences in patient characteristics, assays for TNF $\alpha$, and study designs probably each contribute to the somewhat inchoate picture that emerges, highlighting the pleiotropic and oftentimes unpredictable nature of TNF $\alpha$.

In addition to systemic production of TNF $\alpha$, local production of TNF $\alpha$ may contribute to SLE. Studies of local production of TNF $\alpha$ in the kidneys have documented upregulated TNF $\alpha$ protein and gene expression in renal biopsy tissue from $52 \%$ of SLE nephritis patients [22]. Local upregulated TNF $\alpha$ protein and gene expression within the resident glomerular, tubular, and mesangial cells has also been demonstrated [23].

The effects of systemically produced TNF $\alpha$ may be dissociated from the effects of locally produced TNF $\alpha$. For example, DR3-positive or DR4-positive SLE patients, who genetically are high TNF $\alpha$ producers in response to appropriate induction, are not predisposed to nephritis. In contrast, DR2 and DQw1-positive SLE patients, who genetically are low TNFo producers following induction, have an increased incidence of SLE nephritis [44]. As another example, the TNF $\alpha$ adaptor proteins TNF receptor type 1-associated DEATH domain (TRADD), FADD, receptor interacting protein-1 (RIP-1), and 
TRAF-2 are downregulated in SLE peripheral blood mononuclear cells, and their decreased expression correlates with disease activity [45]. The downregulation of TRADD and FADD (which can recruit the caspase cascade) may thus promote an anti-apoptotic effect that leads to survival of autoreactive cells. Of note, TRADD, RIP-1, and TRAF-2 (which can activate the NF- $\kappa B$ pathway) are upregulated, rather than downregulated, in renal tissue from SLE nephritis patients, suggesting that TNF $\alpha$ may promote immunoregulatory functions systemically but may mediate inflammation locally [46].

\section{Therapeutic blockade of TNFa in systemic lupus erythematosus}

Use of TNFa antagonists is well established in the treatment of rheumatoid arthritis, juvenile idiopathic arthritis, psoriatic arthritis, chronic inflammatory bowel disease, and ankylosing spondylitis [47]. Consistent with the competing proinflammatory and anti-inflammatory effects of TNF $\alpha$, use of TNF $\alpha$ antagonists in multiple sclerosis patients has led to immune activation and disease exacerbation [48]. Moreover, TNF $\alpha$ antagonists have triggered the development of autoantibodies, neuroinflammatory disease, or SLE-like features in some patients with rheumatoid arthritis or chronic inflammatory bowel disease [49-51]. Indeed, depending on the disease, two-thirds of previously antinuclear antibody (ANA)-negative patients became ANA-positive after initiation of TNF $\alpha$-antagonist therapy. A recent report described six rheumatoid arthritis patients who developed active SLE associated with major organ involvement and life-threatening manifestations and required additional treatment beyond cessation of the TNF $\alpha$-antagonist regimen [52].

Nevertheless, TNFo-antagonist therapy has been successful in some SLE patients. Six patients with moderately active SLE (three with nephritis, two with arthritis refractory to other therapies, and one with both joint and renal involvement) were given four infusions of $300 \mathrm{mg}$ doses of infliximab, in combination with immunosuppression with azathioprine or methotrexate [53]. Patients with joint involvement experienced remission of arthritis, which relapsed 8 to 11 weeks after the last infliximab infusion. In the four patients with nephritis, proteinuria decreased by $>60 \%$ within 8 weeks. Of note, anti-dsDNA and anti-cardiolipin antibodies increased in four patients. A number of long-term studies also revealed modest clinical benefit, but there were several adverse events, including deep-vein thrombosis, infections, central nervous system lymphoma, and Legionella pneumonia $[54,55]$.

The need to evaluate safety and efficacy of TNF $\alpha$ blockade in SLE prompted two large randomized phase II and phase III trials with etanercept and infliximab
(Table 1), but both studies (NCT00447265 and NCT00368264) were terminated prematurely (although this may have had more to do with corporate business matters than with medical matters). As with neutralization of IL-6, additional studies with TNFo antagonists will be needed before use of such agents becomes a routinely viable option in human SLE.

\section{Type I interferons}

\section{General biology of type I interferon}

Type I interferon represent a large family of cytokines that includes many IFN $\alpha$ subtypes, a single IFN $\beta$, and multiple IFN $\omega$ subtypes that exert their expansive biological properties through engagement of a common heterodimeric receptor (type I interferon receptor (IFNAR)) composed of IFNAR1 and IFNAR2 subunits. These broad effects include activating dendritic cells; promoting proliferation, survival, and differentiation of monocytes into antigen-presenting cells and B cells into plasma cells; stimulating the Th1 pathway and preventing apoptosis of activated cytotoxic $\mathrm{T}$ cells; and suppressing regulatory $\mathrm{T}$ cells, enhancing natural killer cell activity, and modulating each of these cells' respective cytokine production and signaling responses.

Within the type I interferon family, the IFNo subtypes are arguably the biologically most important in general, and this certainly is the case for SLE. The major producers of IFN $\alpha$ are plasmacytoid dendritic cells, although virtually any cell type can elaborate interferon [56]. IFN $\alpha$ is produced both in response to exogenous stimuli, such as bacterial and viral pathogens, and to endogenous stimuli, such as self-nucleic acids and nucleic acid-containing immune complexes, via Toll-like receptor (TLR)-dependent and TLR-independent pathways. Among the TLR-dependent pathways, engagement of TLR7 and TLR8 by single-strand RNA-containing complexes and engagement of TLR9 by dsDNA-containing complexes may be especially relevant to SLE pathogenesis [56].

\section{Type I interferon in murine lupus}

Numerous studies have collectively demonstrated the complexity of the type I interferon/IFNAR axis in the pathogenesis of murine SLE. In several strains of mice with SLE-related autoimmune phenotypes, type I interferon/IFNAR signaling promotes autoantibody production and development of renal disease. Indeed, genetic deletion of the Ifnar1 gene prevents the development of severe clinical and pathological disease in SLEprone NZB and NZM2328 mice $[57,58]$. Similarly, upregulation or administration of IFNa to BWF mice, (NZWxBXSB)F1 mice, B6.Sle123 mice, or NZM2328 mice markedly accelerates nephritis and death [59-61], and in BWF mice is associated with unabated expansion 
of short-lived plasma cells [62]. Nevertheless, type I interferon/IFNAR signaling is not always deleterious. IFNAR-deficient MRL/lpr mice develop more severe disease than do their IFNAR-sufficient counterparts [63], an observation that may relate to the ability of IFN $\beta$ to ameliorate disease manifestations in MRL/lpr mice. Importantly, these counterintuitive effects of type I interferon are not limited to MRL/lpr mice, in that blockade of type I interferon in B57BL/6 or B6.Sle2 mice led to increased, rather than decreased, levels of IgG autoantibodies [64].

In addition to studies that directly manipulated type I interferon and/or IFNAR expression, studies focused on TLR (especially TLR7 and TLR9) have also pointed to a vital role for IFNo in murine SLE. Interestingly, TLR7/9 doubly-deficient $\mathrm{MRL} / \mathrm{lpr}$ mice display significantly reduced ANA titers, proteinuria, and kidney disease [65]. In agreement with these results, treatment of BWF mice with a dual inhibitor of TLR7 and TLR9 demonstrated significant reductions in interferon produced by plasmacytoid dendritic cells; decreased proteinuria; reduced glomerulonephritis, serum autoantibody levels, and endorgan damage; and increased survival [66]. Indeed, administration of bacterial or viral TLR ligands to SLEprone mice leads to increased IFNa production and disease exacerbation, whereas disease is not exacerbated in similarly treated IFNAR-deficient SLE-prone mice [67].

\section{Type I interferon and human systemic lupus erythematosus}

Serum type I interferon activity is increased in SLE patients and their first-degree relatives, and ages of peak type I interferon are associated with ages of peak SLE incidence [68,69]. Type I interferon levels have correlated with disease activity in a number of cross-sectional studies, although longitudinal correlations could not be established in other studies [70-72]. The use of elevated serum levels of type I interferon-regulated chemokines as biomarkers for disease activity was suggested in early studies [73] and was later replicated and validated by associations between elevated transcript levels of these chemokines with disease activity and organ damage $[74,75]$. By relying on expression of type I interferoninducible genes rather than on circulating type I interferon protein levels (which are often barely detectable or not detectable), most SLE patients have been demonstrated to unequivocally express type I interferoninducible genes in peripheral blood mononuclear cells. This so-called interferon signature has been convincingly correlated with active disease, renal manifestations, and increased damage index [70,76,77]. Furthermore, the interferon gene signature has been found in glomerular and synovial tissue, suggesting local organ involvement of type I interferon $[78,79]$. Indeed, plasmacytoid dendritic cells - the main producers of IFN $\alpha$ - accumulate in the glomeruli of SLE nephritis patients and can also be found in cutaneous lesions where they promote continuous IFN $\alpha$ release $[80,81]$.

In terms of potential interferon contribution to lymphocyte autoreactivity in SLE, interferon not only promotes B-cell activation, antibody production, and class switching, but can also decrease B-cell selectivity for CpG-rich DNA, thereby activating TLR9, and can also allow stimulation of $\mathrm{B}$ cells by non-CpG DNA $[82,83]$. Moreover, interferon can potentially promote survival of autoreactive B cells, since it can prevent B-cell apoptosis and enhance proliferation even in the absence of mitogenic stimuli [84].

T-cell function is also modulated by interferon in SLE. Ample literature has demonstrated dysfunction of regulatory $\mathrm{T}$ cells in SLE, with SLE regulatory $\mathrm{T}$ cells being inefficient suppressors of inflammation and T-cell proliferation $[85,86]$. Part of this dysfunction appears to be due to interferon production by antigen-presenting cells [87].

The ex vivo and in vitro findings that suggest a role for type I interferon in SLE pathogenesis are supported by the development of SLE or SLE-like syndromes (malar rash, oral ulcers, photosensitivity, renal involvement, and anti-Sm and anti-dsDNA antibodies) following administration of IFN $\alpha[88,89]$. Occasionally, IFN $\alpha$-induced SLE has led to life-threatening multiorgan involvement [90].

Recent investigations into the genetics of SLE have also revealed a strong connection between the type I interferon pathway and SLE. The gene coding for the transcription factor IRF5 was the first gene involved in IFN $\alpha$ production to be associated with SLE susceptibility [91]. Further evidence of genetic association between SLE and IRF5 and for interaction between IRF5 and TYK2, a Janus kinase involved in cytokine signaling that binds to IFNAR, has also been demonstrated [92]. Moreover, IRF5 risk loci are also associated with high serum type I interferon activity and the development of autoantibodies to dsDNA and RNA-binding proteins. [93]. Subsequently, the related IRF7 has also been associated with SLE [94]. Furthermore, the STAT4 gene, which codes for a protein that interacts with the cytoplasmic portion of IFNAR, is strongly associated with SLE. STAT4 risk loci increase sensitivity to IFN $\alpha$, are associated with a more severe phenotype that includes anti-dsDNA antibodies and renal involvement, and interact with IRF5 susceptibility loci [95-97]. Another SLE susceptibility gene codes for IRAK1, which is involved in TLR-triggered signal transduction [98].

IFN $\alpha$, independent of its effects on the immune system, may be especially important in promoting atherosclerotic disease in SLE. The dysfunction of circulating endothelial progenitor cells and myelomonocytic circulating 
angiogenic cells in SLE appears to be mediated by IFN $\alpha$, in as much as neutralization of IFN $\alpha$ restores a normal endothelial progenitor cell/circulating angiogenic cell phenotype [99]. Indeed, SLE patients with robust interferon signatures have decreased endothelial function [100], and interferon signatures correlate with carotid intima media thickness [101].

\section{Therapeutic blockade of type I interferon in systemic lupus erythematosus}

The fact that type I interferon exacerbates SLE in some mouse strains but ameliorates SLE in others [59-61,63] raises the possibility that markedly divergent clinical responses to type I interferon antagonists might emerge among individual SLE patients. Experience to date with antagonists against type I interferon in SLE is very limited (Table 1$)$. Treatment of SLE patients $(n=62)$ in a phase I trial with anti-IFN $\alpha$ mAb sifalimumab (MEDI-545) in single escalating intravenous doses of $0.3,1.0,3.0,10.0$, or $30.0 \mathrm{mg} / \mathrm{kg}$ led to dose-dependent reversal of the interferon signature in both the blood and skin, downregulation of several cytokines, and reduced disease activity without any increase in serious infections [102]. Results from a phase I trial with the anti-IFN $\alpha \mathrm{mAb}$ rontalizumab (rhuMab IFN- $\alpha$ ) in SLE patients $(n=32)$ replicated this dose-dependent reduction in the interferon signature [103]. Two phase II trials are currently ongoing to evaluate the effects of anti-IFN $\alpha$ in SLE (NCT01031836 and NCT00657189), but as yet it will be some time before the utility of type I interferon antagonists in SLE is known.

\section{B-lymphocyte stimulator General biology of BLyS}

BLyS (also known as BAFF) is a cytokine that is essential for survival of most $B$ cells beyond the transitional 1 stage [104]. BLyS binds to three receptors: BCMA, TACI, and BR3 (also known as BAFFR). Two of these receptors (BCMA and TACI), but not the third (BR3), also bind APRIL, a cytokine closely related to BLyS that shares some, but not all, of its biological properties. Whereas survival of plasma cells, which express TACI and BCMA, is supported by either BLyS or APRIL, the survival of preplasmablast mature B cells, which express much BR3 but little TACI and essentially no BCMA, is supported only by BLyS. Of note, memory B cells appear to be independent of both BLyS and APRIL.

In addition to affecting B-cell survival/function, BLyS can affect other cell types that express BLyS receptors. Specifically, BR3 is expressed on T cells, although its role in T-cell signaling/stimulation is controversial [104]. Moreover, dendritic cells also express BLyS receptors, and BLyS-stimulated dendritic cells upregulate co-stimulatory molecules and produce inflammatory cytokines and chemokines such as IL-1, IL-6, CCL2, and CCL5.

\section{BLyS in murine systemic lupus erythematosus}

There is an irrefutable link between BLyS and murine SLE. Constitutive overexpression of BLyS in BLyS-transgenic nonautoimmune-prone mice leads to SLE-like features, including elevated levels of multiple autoantibodies (including anti-dsDNA), circulating immune complexes, and glomerular immunoglobulin deposition [105]. Moreover, BLyS overexpression accelerates the development of SLE-like features in mice that bear an autoimmune diathesis but otherwise do not develop overt SLE [106]. On the other hand, SLE-prone NZM2328 mice genetically deficient in BLyS are largely spared from overt disease (severe proteinuria and premature death), although the lifelong absence of BLyS does not protect them from ultimately developing serological autoimmunity and renal pathology [107]. Most importantly, treatment of BWF mice, (NZMxBXSB)F1 mice, MRL/lpr mice, or NZM2410 mice with either TACI-Ig (which neutralizes both BLyS and APRIL) or BR3-Ig (which selectively neutralizes BLyS) is effective at preventing clinical disease and ameliorating renal injury [108]. Intriguingly, IFNo-driven exaggerated disease in several SLE-prone mouse strains is associated with increases in serum BLyS levels [59-61], and IFN $\alpha$-driven exaggerated disease is completely blocked in BLySdeficient NZM2328 mice [109], indicating that BLyS is a vital contributor to the IFN $\alpha$-driven pathogenic pathway in SLE.

\section{BLyS in human systemic lupus erythematosus}

Not only is BLyS associated with murine SLE, but is also associated with human SLE. Circulating BLyS levels are elevated in as many as 50\% of SLE patients [110], and disease activity correlates with blood leukocyte expression of BLyS mRNA [111]. Aberrant expression of BLyS on multiple immune cells has been observed in SLE. Although BLyS is largely expressed in myeloid lineage cells, activated $B$ cells can also express both BLyS and APRIL. In SLE patients, B cells and plasma cells express high levels of BLyS and APRIL mRNA, which correlate with disease activity and levels of anti-dsDNA antibodies [112].

In addition to the biologic studies summarized above, investigations into genetic susceptibility loci in SLE have revealed associations between polymorphisms in BLyS and APRIL genes with human SLE $[113,114]$. In light of the results from murine SLE models, from ex vivo studies of human SLE leukocytes, from BLyS serum analyses, and from the genetics of SLE, BLyS has emerged as a highly attractive cytokine target in SLE.

\section{Therapeutic blockade of BLyS in human systemic lupus erythematosus}

The greatest experience to date with BLyS antagonists (Table 1) has accrued with belimumab, a fully human 
$\mathrm{IgG}_{1 \lambda} \mathrm{mAb}$ that binds and neutralizes soluble BLyS [115]. Belimumab was shown to be safe in a randomized, double-blind, placebo-controlled phase I trial of SLE, in which the prevalence of adverse events was no different between belimumab-treated and placebo-treated patients [116]. Of note, only modest reductions in peripheral blood B cells were observed among belimumab-treated patients. No clinical efficacy was demonstrated in this phase I trial, but the small number of patients $(n=70)$ and the very brief treatment schedules (single infusion or two infusions 3 weeks apart) and follow-up period (12 weeks after final infusion) precluded demonstration of clinical benefit.

Disappointingly, the subsequent phase II trial $(n=449)$ failed to meet its co-primary endpoints [117]. Extensive post hoc analysis, however, led to a novel composite index of clinical response (SLE responder index) [118] and demonstrated significantly increased clinical response among belimumab-treated patients at 52 weeks among the patients who were seropositive (ANA titer $\geq 1: 80$ and/ or positive for anti-dsDNA antibodies) at entry. Using this novel SLE responder index, two separate large randomized, double-blind, placebo-controlled phase III trials ( $n=865$ and $n=819$, respectively) of belimumab in seropositive SLE patients each met their primary endpoints (increased percentage of responders at 52 weeks) $[119,120]$. Importantly, analysis of the combined 1,864 SLE patients in both trials pointed to reductions in disease activity and prevention of worsening across vital internal organ systems [121]. Although questions remain regarding the durability of the clinical response, a US Food and Drug Administration advisory panel in November 2010 recommended approval for belimumab in the treatment of SLE, and final approval by the US Food and Drug Administration was given on 9 March 2011.

Concern has been raised regarding the ostensibly lower clinical efficacy of belimumab in human SLE in comparison with the ostensibly more robust clinical efficacy of BLyS antagonists in murine SLE. This difference in clinical response between human and murine SLE may be more apparent than real. First, the clinical response in the phase III human trials was based on a composite of several instruments each rooted in multiple organ systems [118]. In contrast, clinical response in the murine trials was simply the absence of pre-moribund proteinuria and death. (Belimumab in all likelihood will prove to be very effective in preventing pre-moribund proteinuria and death; however, it will take many years of follow-up to formally prove this point.) Second, human SLE patients received standard-of-care therapy in addition to belimumab in the human clinical trials, whereas murine SLE patients in the murine clinical trials received no treatment other than a BLyS antagonist. (Human SLE patients treated with belimumab alone would undoubtedly do much better than untreated patients, but such a human trial would be entirely unethical.)

In addition to belimumab, several other BLyS antagonists are undergoing clinical evaluation in SLE. The one furthest advanced in clinical evaluation is atacicept, a fusion protein between one of the BLyS receptors (TACI) and the Fc portion of IgG. Favorable safety and tolerability were demonstrated in a randomized, doubleblind, placebo-controlled phase I trial $(n=49)$ [122]. Dose-dependent reductions in peripheral blood B cells and in circulating immunoglobulin levels were noted, but clinical efficacy could not be demonstrated due to the limited treatment and limited follow-up period. Of concern, an increased risk of severe infections was observed in a subsequent trial involving patients with SLE nephritis who were concurrently taking mycophenolate mofetil and corticosteroids (NCT00573157). As a consequence, this trial was prematurely terminated. Nevertheless, a separate phase II/III trial of atacicept in SLE has recently been initiated (NCT00624338). Whether atacicept achieves clinical success from efficacy and safety standpoints remains to be determined.

A third BLyS antagonist being tested in clinical trials is A-623 (previously known as AMG 623), a fusion between the Fc portion of IgG and a peptide sequence selected for its ability to bind with high affinity to BLyS. In a doubleblind, placebo-controlled phase I trial, SLE patients received a single dose $(n=54)$ or four weekly doses ( $n=63$ ) of escalating doses of AMG 623 or matching placebo [123]. A dose-independent decrease in naive and total peripheral blood B cells was accompanied by an increase in memory B cells - an observation that has now also been made in patients treated with atacicept or belimumab [122,124]. Clinical responses were not reported, so the relevance of the disparate changes among B-cell subsets to clinical parameters remains unknown. A phase II trial of A-623 in SLE had been initiated but was suspended due to 'structural failure identified in some product vials', but the trial was recently resumed (NCT01162681).

A fourth BLyS antagonist in clinical development for SLE is LY2127399, a mAb that binds both soluble and membrane BLyS [125]. Two phase III trials in SLE are planned (NCT01205438 and NCT01196091), but neither has yet started recruiting patients. It remains to be determined whether neutralization of soluble plus membrane BLyS (as with LY2127399) will have greater therapeutic efficacy than neutralization of soluble BLyS alone (as with belimumab).

\section{Concluding remarks}

Cytokine-targeted therapy may prove effective in the treatment of SLE and offer less toxic options 
in comparison with 'conventional' therapies such as glucocorticoids or cytotoxics. In addition to the four cytokines reviewed above, there are many more cytokines - including IFN $\gamma$, IL-1, and IL-17 - that have been implicated in SLE. As has become painfully evident, cytokine biology is extremely complex - and increasingly so in a complex disease such as SLE. Continued investigations of cytokine pathways in vivo in animal models, ex vivo in human SLE tissues, and in the genetics of SLE will reveal the roles of additional cytokines in disease pathogenesis and should offer additional novel targets for treatment.

Autoimmune Basis of Rheumatic Diseases

This article is part of a series on Systemic lupus erythematosus, edited by David Pisetsky, which can be found online at http://arthritis-research.com/series/lupus

This series forms part of a special collection of reviews covering major autoimmune rheumatic diseases, available at:

http://arthritis-research.com/series/abrd

\section{Abbreviations}

ANA, antinuclear antibody; APRIL, a proliferation-inducing ligand; BAFF, B-cell activating factor of the TNF family; BCMA, B-cell maturation antigen; BR3, BLyS receptor 3; BLyS, B-lymphocyte stimulator; BWF, (NZB x NZW)F1; dsDNA, double-strand DNA; FADD, Fas-associated death domain; ICAM-1, intercellular adhesion molecule-1; IFN, interferon; IFNAR, type I interferon receptor; IL, interleukin; IL-6R, IL-6 receptor; mAb, monoclonal antibody; MHC, major histocompatibility complex; NF, nuclear factor; RIP-1, receptor interacting protein-1; SLE, systemic lupus erythematosus; $\mathrm{TACl}$, transmembrane activator and calcium modulator and cyclophilin ligand interactor; Th, T-helper type; TLR, Toll-like receptor; TNF, tumor necrosis factor; TNFR, tumor necrosis factor receptor; TRAF, TNF receptor-associated factor; TRADD, TNF receptor type 1-associated DEATH domain; VCAM-1, vascular cell adhesion molecule-1.

\section{Competing interests}

WS has conducted clinical trials in systemic lupus erythematosus with belimumab (sponsored by Human Genome Sciences). NJ has no competing interests.

\section{Acknowledgements}

The present work was supported in part by a grant from the National Institutes of Health (R01 AR059103) to WS.

Published: 6 July 2011

\section{References}

1. Naka T, Nishimoto N, Kishimoto T: The paradigm of IL-6: from basic science to medicine. Arthritis Res 2002, 4(Suppl 3):S233-S242.

2. Cash H, Relle M, Menke J, Brochhausen C, Jones SA, Topley N, Galle PR, Schwarting A: Interleukin 6 (IL-6) deficiency delays lupus nephritis in MRLFaslpr mice: the IL-6 pathway as a new therapeutic target in treatment of autoimmune kidney disease in systemic lupus erythematosus. $J$ Rheumatol 2010, 37:60-70.

3. Schiffer L, Bethunaickan R, Ramanujam M, Huang W, Schiffer M, Tao H, Madaio MP, Bottinger EP, Davidson A: Activated renal macrophages are markers of disease onset and disease remission in lupus nephritis. J Immunol 2008, 180:1938-1947.

4. Alarcón-Riquelme ME, Möller G, Fernández C: Age-dependent responsiveness to interleukin- 6 in $B$ lymphocytes from a systemic lupus erythematosus-prone (NZB x NZW)F1 hybrid. Clin Immunol Immunopathol 1992, 62:264-269

5. Mihara M, Fukui H, Koishihara Y, Saito M, Ohsugi Y: Immunologic abnormality in NZB/W F1 mice. Thymus-independent expansion of B cells responding to interleukin-6. Clin Exp Immunol 1990, 82:533-537.

6. Alarcón-Riquelme ME, Möller G, Fernández C: Macrophage depletion decreases IgG anti-DNA in cultures from (NZB x NZW)F1 spleen cells by eliminating the main source of IL-6. Clin Exp Immunol 1993, 91:220-225.

7. Ryffel B, Car BD, Gunn H, Roman D, Hiestand P, Mihatsch MJ: Interleukin-6 exacerbates glomerulonephritis in (NZB x NZW)F1 mice. Am J Pathol 1994, 144:927-937.

8. Finck BK, Chan B, Wofsy D: Interleukin 6 promotes murine lupus in NZB/ NZW F1 mice. J Clin Invest 1994, 94:585-591.

9. Mihara M, Takagi N, Takeda Y, Ohsugi Y: IL-6 receptor blockage inhibits the onset of autoimmune kidney disease in NZB/W F1 mice. Clin Exp Immunol 1998, 112:397-402.

10. Richards HB, Satoh M, Shaw M, Libert C, Poli V, Reeves WH: Interleukin 6 dependence of anti-DNA antibody production: evidence for two pathways of autoantibody formation in pristane-induced lupus. J Exp Med 1998, 188:985-990

11. Pflegerl P, Vesely P, Hantusch B, Schlederer M, Zenz R, Janig E, Steiner G, Meixner A, Petzelbauer P, Wolf P, Soleiman A, Egger G, Moriggl R, Kishimoto T, Wagner EF, Kenner L: Epidermal loss of JunB leads to a SLE phenotype due to hyper IL-6 signaling. Proc Natl Acad Sci U S A 2009, 106:20423-20428.

12. Gröndal G, Gunnarsson I, Rönnelid J, Rogberg S, Klareskog L, Lundberg I: Cytokine production, serum levels and disease activity in systemic lupus erythematosus. Clin Exp Rheumatol 2000, 18:565-570.

13. Linker-Israeli M, Deans RJ, Wallace DJ, Prehn J, Ozeri-Chen T, Klinenberg JR: Elevated levels of endogenous IL-6 in systemic lupus erythematosus. A putative role in pathogenesis. J Immuno/ 1991, 147:117-123.

14. Peterson E, Robertson AD, Emlen W: Serum and urinary interleukin-6 in systemic lupus erythematosus. Lupus 1996, 5:571-575.

15. Hagiwara E, Gourley MF, Lee S, Klinman DK: Disease severity in patients with systemic lupus erythematosus correlates with an increased ratio of interleukin-10:interferon-gamma-secreting cells in the peripheral blood. Arthritis Rheum 1996, 39:379-385.

16. Esposito P, Balletta MM, Procino A, Postiglione L, Memoli B: Interleukin-6 release from peripheral mononuclear cells is associated to disease activity and treatment response in patients with lupus nephritis. Lupus 2009, 18:1329-1330

17. Kitani A, Hara M, Hirose T, Norioka K, Harigai M, Hirose W, Suzuki K, Kawakami $M$, Kawagoe M, Nakamura H: Heterogeneity of B cell responsiveness to interleukin 4, interleukin 6 and low molecular weight $B$ cell growth factor in discrete stages of $B$ cell activation in patients with systemic lupus erythematosus. Clin Exp Immunol 1989, 77:31-36.

18. Nagafuchi H, Suzuki N, Mizushima Y, Sakane T: Constitutive expression of IL-6 receptors and their role in the excessive B cell function in patients with systemic lupus erythematosus. J Immunol 1993, 151:6525-6534.

19. Takeno M, Nagafuchi H, Kaneko S, Wakisaka S, Oneda K, Takeba Y, Yamashita $\mathrm{N}$, Suzuki N, Kaneoka H, Sakane T: Autoreactive T cell clones from patients with systemic lupus erythematosus support polyclonal autoantibody production. J Immunol 1997, 15:3529-3538

20. Hirohata S, Kanai Y, Mitsuo A, Tokano Y, Hashimoto H; NPSLE Research Subcommittee: Accuracy of cerebrospinal fluid IL-6 testing for diagnosis of lupus psychosis. A multicenter retrospective study. Clin Rheumatol 2009, 28:1319-1323

21. Imano M, Dohi K, Hirata E, Kurumatani N, Horii Y, Shiiki H, Fukatsu A, Matsuda T, Hirano T, Kishimoto T: Urinary levels of IL-6 in patients with active lupus nephritis. Clin Nephrol 1993, 40:16-21.

22. Herrera-Esparza R, Barbosa-Cisneros O, Villalobos-Hurtado R, Avalos-Díaz E: Renal expression of IL-6 and TNFa genes in lupus nephritis. Lupus 1998, 7:154-158.

23. Malide D, Russo P, Bendayan M: Presence of tumor necrosis factor alpha and interleukin-6 in renal mesangial cells of lupus nephritis patients. Hum Pathol 1995, 26:558-564.

24. Illei GG, Shirota Y, Yarboro CH, Daruwalla J, Tackey E, Takada K, Fleisher T, Balow JE, Lipsky PE. Tocilizumab in systemic lupus erythematosus: data on safety, preliminary efficacy, and impact on circulating plasma cells from an open-label phase I dosage-escalation study. Arthritis Rheum 2010, 62:542-552.

25. MacEwan DJ: TNF ligands and receptors - a matter of life and death. Br J Pharmacol 2002, 135:855-875.

26. McDevitt $\mathrm{H}$, Munson $\mathrm{S}$, Ettinger $\mathrm{R}$, Wu A: Multiple roles for tumor necrosis factor-alpha and lymphotoxin alpha/beta in immunity and autoimmunity. 
Arthritis Res 2002, 4(Suppl 3):S141-S152.

27. Boswell JM, Yui MA, Burt DW, Kelley VE: Increased tumor necrosis factor and IL-1 beta gene expression in the kidneys of mice with lupus nephritis. J Immunol 1988, 141:3050-3054.

28. Yokoyama H, Kreft B, Kelley VR: Biphasic increase in circulating and renal TNF-a in MRL-Ipr mice with differing regulatory mechanisms. Kidney Int 1995, 47:122-130

29. Edwards CK III, Zhou T, Zhang J, Baker TJ, De M, Long RE, Borcherding DR, Bowlin TL, Bluethmann H, Mountz JD: Inhibition of superantigen-induced proinflammatory cytokine production and inflammatory arthritis in MRL-Ipr/Ipr mice by a transcriptional inhibitor of TNF-a. J Immunol 1996, 157:1758-1772.

30. Segal R, Dayan M, Zinger H, Mozes E: Suppression of experimental systemic lupus erythematosus (SLE) in mice via TNF inhibition by an anti-TNFa monoclonal antibody and by pentoxiphylline. Lupus 2001, 10:23-31.

31. Jacob CO, McDevitt HO: Tumour necrosis factor-alpha in murine autoimmune 'lupus' nephritis. Nature 1988, 331:356-358.

32. Gordon C, Ranges GE, Greenspan JS, Wofsy D: Chronic therapy with recombinant tumor necrosis factor-alpha in autoimmune NZB/NZW F1 mice. Clin Immunol Immunopathol 1989, 52:421-434.

33. Gordon C, Wofsy D: Effects of recombinant murine tumor necrosis factoralpha on immune function. J Immunol 1990, 144:1753-1758.

34. Kontoyiannis D, Kollias $\mathrm{G}$ : Accelerated autoimmunity and lupus nephritis in NZB mice with an engineered heterozygous deficiency in tumor necrosis factor. Eur J Immunol 2000, 30:2038-2047.

35. Kollias G, Kontoyianni D: Role of TNF/TNFR in autoimmunity: specific TNF receptor blockade may be advantageous to anti-TNF treatments. Cytokine Growth Factor Rev 2002, 13:315-321.

36. Vielhauer V, Mayadas TN: Functions of TNF and its receptors in renal disease: distinct roles in inflammatory tissue injury and immune regulation. Semin Nephrol 2007, 27:286-308.

37. Vielhauer V, Stavrakis G, Mayadas TN: Renal cell-expressed TNF receptor 2, not receptor 1 , is essential for the development of glomerulonephritis. J Clin Invest 2005, 115:1199-1209.

38. Zhou T, Edwards CK 3rd, Yang P, Wang Z, Bluethmann H, Mountz JD: Greatly accelerated lymphadenopathy and autoimmune disease in Ipr mice lacking tumor necrosis factor receptor I. J Immunol 1996, 156:2661-2665.

39. Jacob N, Yang H, Pricop L, Liu Y, Gao X, Zheng SG, Wang J, Gao HX, Putterman C, Koss MN, Stohl W, Jacob CO: Accelerated pathological and clinical nephritis in systemic lupus erythematosus-prone New Zealand Mixed 2328 mice doubly deficient in TNF receptor 1 and TNF receptor 2 via a Th17-associated pathway. J Immunol 2009, 182:2532-2541.

40. Studnicka-Benke A, Steiner G, Petera P, Smolen JS: Tumour necrosis factor alpha and its soluble receptors parallel clinical disease and autoimmune activity in systemic lupus erythematosus. Br J Rheumatol 1996, 35:1067-1074

41. Gabay C, Cakir N, Moral F, Roux-Lombard P, Meyer O, Dayer JM, Vischer T, Yazici $H$, Guerne PA: Circulating levels of tumor necrosis factor soluble receptors in systemic lupus erythematosus are significantly higher than in other rheumatic diseases and correlate with disease activity. $J$ Rheumatol 1997, 24:303-308

42. Zhu L, Landolt-Marticorena C, Li T, Yang X, Yu XQ, Gladman DD, Urowitz MB, Fortin PR, Wither JE: Altered expression of TNF-a signaling pathway proteins in systemic lupus erythematosus. J Rheumatol 2010, 37:1658-1666.

43. Gómez D, Correa PA, Gómez LM, Cadena J, Molina JF, Anaya JM: Th1/Th2 cytokines in patients with systemic lupus erythematosus: is tumor necrosis factor alpha protective? Semin Arthritis Rheum 2004, 33:404-413.

44. Jacob CO, Fronek Z, Lewis GD, Koo M, Hansen JA, McDevitt HO: Heritable major histocompatibility complex class II-associated differences in production of tumor necrosis factor alpha: relevance to genetic predisposition to systemic lupus erythematosus. Proc Natl Acad Sci U S A 1990, 87:1233-1237

45. Zhu L, Yang X, Chen W, Li X, Ji Y, Mao H, Nie J, Yu X: Decreased expressions of the TNF-a signaling adapters in peripheral blood mononuclear cells (PBMCs) are correlated with disease activity in patients with systemic lupus erythematosus. Clin Rheumatol 2007, 26:1481-1489.

46. Zhu L, Yang X, Ji Y, Chen W, Guan W, Zhou SF, Yu X: Up-regulated renal expression of TNF-a signaling adapter proteins in lupus glomerulonephritis. Lupus 2009, 18:116-127.

47. Elliott MJ, Maini RN, Feldmann M, Kalden JR, Antoni C, Smolen JS, Leeb B, Breedveld FC, Macfarlane JD, Bijl H: Randomised double-blind comparison of chimeric monoclonal antibody to tumour necrosis factor alpha (CA2) versus placebo in rheumatoid arthritis. Lancet 1994, 344:1105-1110.

48. Lenercept Multiple Sclerosis Study Group; University of British Columbia MS/ MRI Analysis Group: TNF neutralization in MS: results of a randomized, placebo-controlled multicenter study. Neurology 1999, 53:457-465.

49. Feldmann M, Brennan FM, Maini RN: Role of cytokines in rheumatoid arthritis. Annu Rev Immunol 1996, 14:397-440.

50. Sicotte NL, Voskuhl RR: Onset of multiple sclerosis associated with anti-TNF therapy. Neurology 2001, 57:1885-1888.

51. Sandborn WJ, Hanauer SB: Antitumor necrosis factor therapy for inflammatory bowel disease: a review of agents, pharmacology, clinical results, and safety. Inflamm Bowel Dis 1999, 5:119-133.

52. Soforo E, Baumgartner M, Francis L, Allam F, Phillips PE, Perl A: Induction of systemic lupus erythematosus with tumor necrosis factor blockers. J Rheumatol 2010, 37:204-205.

53. Aringer M, Graninger WB, Steiner G, Smolen JS: Safety and efficacy of tumor necrosis factor alpha blockade in systemic lupus erythematosus: an openlabel study. Arthritis Rheum 2004, 50:3161-3169.

54. Matsumura R, Umemiya K, Sugiyama T, Sueishi M, Umibe T, Ichikawa K, Yoshimura M: Anti-tumor necrosis factor therapy in patients with difficultto-treat lupus nephritis: a prospective series of nine patients. Clin Exp Rheumatol 2009, 27:416-421.

55. Aringer M, Houssiau F, Gordon C, Graninger WB, Voll RE, Rath E, Steiner G, Smolen JS: Adverse events and efficacy of TNF-a blockade with infliximab in patients with systemic lupus erythematosus: long-term follow-up of 13 patients. Rheumatology (Oxford) 2009, 48:1451-1454.

56. Baccala R, Hoebe K, Kono DH, Beutler B, Theofilopoulos AN: TLR-dependent and TLR-independent pathways of type I interferon induction in systemic autoimmunity. Nat Med 2007, 13:543-551.

57. Santiago-Raber M-L, Baccala R, Haraldsson KM, Choubey D, Stewart TA, Kono $\mathrm{DH}$, Theofilopoulos AN: Type-I interferon receptor deficiency reduces lupus-like disease in NZB mice. J Exp Med 2003, 197:777-788.

58. Agrawal H, Jacob N, Carreras E, Bajana S, Putterman C, Turner S, Neas B, Mathian A, Koss MN, Stohl W, Kovats S, Jacob CO: Deficiency of type I IFN receptor in lupus-prone New Zealand mixed 2328 mice decreases dendritic cell numbers and activation and protects from disease. J Immunol 2009, 183:6021-6029.

59. Mathian A, Weinberg A, Gallegos M, Banchereau J, Koutouzov S: IFN-a induces early lethal lupus in preautoimmune (New Zealand Black $x$ New Zealand White) F1 but not in BALB/c mice. J Immuno/ 2005, 174:2499-2506.

60. Fairhurst AM, Mathian A, Connolly JE, Wang A, Gray HF, George TA, Boudreaux CD, Zhou XJ, Li QZ, Koutouzov S, Banchereau J, Wakeland EK: Systemic IFN-a drives kidney nephritis in B6.Sle123 mice. Eur J Immunol 2008, 38:1948-1960.

61. Ramanujam M, Kahn P, Huang W, Tao H, Madaio MP, Factor SM, Davidson A Interferon-alpha treatment of female (NZW x BXSB)F(1) mice mimics some but not all features associated with the Yaa mutation. Arthritis Rheum 2009. 60:1096-1101.

62. Mathian A, Gallegos M, Pascual V, Banchereau J, Koutouzov S: Interferon-a induces unabated production of short-lived plasma cells in preautoimmune lupus-prone (NZB X NZW)F1 mice but not in BALB/c mice. Eur I Immunol 2011, 41:863-872.

63. Hron JD, Peng SL: Type I IFN protects against murine lupus. J /mmuno/ 2004 , 173:2134-2142.

64. Li J, Liu Y, Xie C, Zhu J, Kreska D, Morel L, Mohan C: Deficiency of type interferon contributes to Sle2-associated component lupus phenotypes. Arthritis Rheum 2005, 52:3063-3072.

65. Nickerson KM, Christensen SR, Shupe J, Kashgarian M, Kim D, Elkon K, Shlomchik MJ: TLR9 regulates TLR7- and MyD88-dependent autoantibody production and disease in a murine model of lupus. I Immunol 2010, 184:1840-1848.

66. Barrat FJ, Meeker T, Chan JH, Guiducci C, Coffmann RL: Treatment of lupusprone mice with a dual inhibitor of TLR7 and TLR9 leads to reduction of autoantibody production and amelioration of disease symptoms. Eur J Immunol 2007, 37:3582-3586.

67. Theofilopoulos AN, Baccala R, Beutler B, Kono DH: Type I interferons (alpha/ beta) in immunity and autoimmunity. Annu Rev Immunol 2005, 23:307-336.

68. Niewold TB, Hua J, Lehman TJ, Harley JB, Crow MK: High serum IFN- $a$ activity is a heritable risk factor for systemic lupus erythematosus. Genes Immun 2007, 8:492-502.

69. Niewold TB, Adler JE, Glenn SB, Lehman TJ, Harley JB, Crow MK: Age- and 
sex-related patterns of serum interferon-alpha activity in lupus families. Arthritis Rheum 2008, 58:2113-2119.

70. Kirou KA, Lee C, George S, Louca K, Peterson MG, Crow MK: Activation of the interferon-alpha pathway identifies a subgroup of systemic lupus erythematosus patients with distinct serologic features and active disease. Arthritis Rheum 2005, 52:1491-1503.

71. Dall'era MC, Cardarelli PM, Preston BT, Witte A, Davis JC Jr: Type I interferon correlates with serological and clinical manifestations of SLE. Ann Rheum Dis 2005, 64:1692-1697.

72. Landolt-Marticorena C, Bonventi G, Lubovich A, Ferguson C, Unnithan T, Su J, Gladman DD, Urowitz M, Fortin PR, Wither J: Lack of association between the interferon-alpha signature and longitudinal changes in disease activity in systemic lupus erythematosus. Ann Rheum Dis 2009, 68:1440-1446.

73. Bauer JW, Baechler EC, Petri M, Batliwalla FM, Crawford D, Ortmann WA, Espe KJ, Li W, Patel DD, Gregersen PK, Behrens TW: Elevated serum levels of interferon-regulated chemokines are biomarkers for active human systemic lupus erythematosus. PLoS Med 2006, 3:e491.

74. Fu Q, Chen X, Cui H, Guo Y, Chen J, Shen N, Bao C: Association of elevated transcript levels of interferon-inducible chemokines with disease activity and organ damage in systemic lupus erythematosus patients. Arthritis Res Ther 2008, 10:R112.

75. Bauer JW, Petri M, Batliwalla FM, Koeuth T, Wilson J, Slattery C, PanoskaltsisMortari A, Gregersen PK, Behrens TW, Baechler EC: Interferon-regulated chemokines as biomarkers of systemic lupus erythematosus disease activity: a validation study. Arthritis Rheum 2009, 60:3098-3107.

76. Baechler EC, Batliwalla FM, Karypis G, Gaffney PM, Ortmann WA, Espe KJ, Shark KB, Grande WJ, Hughes KM, KapurV, Gregersen PK, Behrens TW: Interferon-inducible gene expression signature in peripheral blood cells of patients with severe lupus. Proc Natl Acad Sci U S A 2003, 100:2610-2615.

77. Bennett L, Palucka AK, Arce E, Cantrell V, Borvak J, Banchereau J, Pascual V: Interferon and granulopoiesis signatures in systemic lupus erythematosus blood. J Exp Med 2003, 197:711-723.

78. Peterson KS, Huang JF, Zhu J, D'Agati V, Liu X, Miller N, Erlander MG, Jackson MR, Winchester RJ: Characterization of heterogeneity in the molecular pathogenesis of lupus nephritis from transcriptional profiles of lasercaptured glomeruli. J Clin Invest 2004, 113:1722-1733.

79. Nzeusseu Toukap A, Galant C, Theate I, Maudoux AL, Lories RJ, Houssiau FA, Lauwerys BR: Identification of distinct gene expression profiles in the synovium of patients with systemic lupus erythematosus. Arthritis Rheum 2007, 56:1579-1588.

80. Tucci M, Quatraro C, Lombardi L, Pellegrino C, Dammacco F, Silvestris F: Glomerular accumulation of plasmacytoid dendritic cells in active lupus nephritis: role of interleukin-18. Arthritis Rheum 2008, 58:251-262.

81. Farkas L, Beiske K, Lund-Johansen F, Brandtzaeg P, Jahnsen FL: Plasmacytoid dendritic cells (natural interferon-alpha/beta-producing cells) accumulate in cutaneous lupus erythematosus lesions. Am J Pathol 2001, 159:237-243.

82. Jego G, Palucka AK, Blanck JP, Chalouni C, Pascual V, Banchereau J: Plasmacytoid dendritic cells induce plasma cell differentiation through type I interferon and interleukin 6. Immunity 2003, 19:225-234.

83. Le Bon A, Thompson C, Kamphuis E, Durand V, Rossmann C, Kalinke U, Tough DF: Cutting edge: enhancement of antibody responses through direct stimulation of B and T cells by type I IFN. J Immunol 2006, 176:2074-2078.

84. Ruuth K, Carlsson L, Hallberg B, Lundgren E: Interferon-alpha promotes survival of human primary B-lymphocytes via phosphatidylinositol 3-kinase. Biochem Biophys Res Commun 2001, 284:583-586.

85. Suen JL, Li HT, Jong YJ, Chiang BL, Yen JH: Altered homeostasis of CD4(+) FoxP3(+) regulatory T-cell subpopulations in systemic lupus erythematosus. Immunology 2009, 127:196-205.

86. Venigalla RK, Tretter T, Krienke S, Max R, Eckstein V, Blank N, Fiehn C, Ho AD, Lorenz HM: Reduced $C D 4+, C D 25-T$ cell sensitivity to the suppressive function of $\mathrm{CD}^{+}, \mathrm{CD} 25^{\text {high }}, \mathrm{CD} 127^{- \text {-low }}$ regulatory T cells in patients with active systemic lupus erythematosus. Arthritis Rheum 2008, 58:2120-2130.

87. Yan B, Ye S, Chen G, Kuang M, Shen N, Chen S: Dysfunctional CD4 $4^{+}, \mathrm{CD}_{25} 5^{+}$ regulatory $T$ cells in untreated active systemic lupus erythematosus secondary to interferon-alpha-producing antigen-presenting cells. Arthritis Rheum 2008, 58:801-812.

88. Rönnblom LE, Alm GV, Oberg KE: Possible induction of systemic lupus erythematosus by interferon-alpha treatment in a patient with a malignant carcinoid tumour. J Intern Med 1990, 227:207-210.

89. Niewold TB, Swedler Wl: Systemic lupus erythematosus arising during interferon-alpha therapy for cryoglobulinemic vasculitis associated with hepatitis C. Clin Rheumatol 2005, 24:178-181.

90. Niewold TB: Interferon alpha-induced lupus: proof of principle. J Clin Rheumatol 2008, 14:131-132.

91. Sigurdsson $\mathrm{S}$, Nordmark G, Göring HH, Lindroos K, Wiman AC, Sturfelt G, Jönsen A, Rantapää-Dahlqvist S, Möller B, Kere J, Koskenmies S, Widén E, Eloranta ML, Julkunen H, Kristjansdottir H, Steinsson K, Alm G, Rönnblom L, Syvänen AC: Polymorphisms in the tyrosine kinase 2 and interferon regulatory factor 5 genes are associated with systemic lupus erythematosus. Am J Hum Genet 2005, 76:528-537.

92. Hellquist $A$, Järvinen TM, Koskenmies S, Zucchelli M, Orsmark-Pietras $C$ Berglind L, Panelius J, Hasan T, Julkunen H, D'Amato M, Saarialho-Kere U, Kere $\mathrm{J}$ : Evidence for genetic association and interaction between the TYK 2 and IRF5 genes in systemic lupus erythematosus. J Rheumatol 2009, 36:1631-1638.

93. Niewold TB, Kelly JA, Flesch MH, Espinoza LR, Harley JB, Crow MK: Association of the IRF5 risk haplotype with high serum interferon-alpha activity in systemic lupus erythematosus patients. Arthritis Rheum 2008, 58:2481-2487.

94. International Consortium for Systemic Lupus Erythematosus Genetics (SLEGEN); Harley JB, Alarcón-Riquelme ME, Criswell LA, Jacob CO, Kimberly RP, Moser KL, Tsao BP, Vyse TJ, Langefeld CD, Nath SK, Guthridge JM, Cobb BL, Mirel DB, Marion MC, Williams AH, Divers J, Wang W, Frank SG, Namjou B, Gabriel SB, Lee AT, Gregersen PK, Behrens TW, Taylor KE, Fernando M, Zidovetzki R, Gaffney PM, Edberg JC, Rioux JD, Ojwang JO, et al.: Genomewide association scan in women with systemic lupus erythematosus identifies susceptibility variants in ITGAM, PXK, KIAA1542 and other loci. Nat Genet 2008, 40:204-210.

95. Kariuki SN, Kirou KA, MacDermott EJ, Barillas-Arias L, Crow MK, Niewold TB: Cutting edge: autoimmune disease risk variant of STAT4 confers increased sensitivity to IFN-alpha in lupus patients in vivo. J Immunol 2009, 182:34-38.

96. Taylor KE, Remmers EF, Lee AT, Ortmann WA, Plenge RM, Tian C, Chung SA, Nititham J, Hom G, Kao AH, Demirci FY, Kamboh MI, Petri M, Manzi S, Kastner DL, Seldin MF, Gregersen PK, Behrens TW, Criswell LA: Specificity of the STAT4 genetic association for severe disease manifestations of systemic lupus erythematosus. PLoS Genet 2008, 4:e1000084.

97. Abelson AK, Delgado-Vega AM, Kozyrev SV, Sánchez E, Velázquez-Cruz R, Eriksson N, Wojcik J, Linga Reddy MV, Lima G, D’Alfonso S, Migliaresi S, Baca V, Orozco L, Witte T, Ortego-Centeno N; AADEA Group; Abderrahim H, PonsEstel BA, Gutiérrez C, Suárez A, González-Escribano MF, Martin J, AlarcónRiquelme ME: STAT4 associates with systemic lupus erythematosus through two independent effects that correlate with gene expression and act additively with IRF5 to increase risk. Ann Rheum Dis 2009, 68:1746-1753.

98. Jacob CO, Zhu J, Armstrong DL, Yan M, Han J, Zhou XJ, Thomas JA, Reiff A, Myones BL, Ojwang JO, Kaufman KM, Klein-Gitelman M, McCurdy D, WagnerWeiner L, Silverman E, Ziegler J, Kelly JA, Merrill JT, Harley JB, RamseyGoldman R, Vila LM, Bae SC, Vyse TJ, Gilkeson GS, Gaffney PM, Moser KL, Langefeld CD, Zidovetzki R, Mohan C: Identification of IRAK1 as a risk gene with critical role in the pathogenesis of systemic lupus erythematosus. Proc Natl Acad Sci U S A 2009, 106:6256-6261.

99. Denny MF, Thacker S, Mehta H, Somers EC, DodickT, Barrat FJ, McCune WJ, Kaplan MJ: Interferon-a promotes abnormal vasculogenesis in lupus: a potential pathway for premature atherosclerosis. Blood 2007, 110:2907-2915.

100. Lee PY, Li Y, Richards HB, Chan FS, Zhuang H, Narain S, Butfiloski EJ, Sobel ES, Reeves WH, Segal MS: Type I interferon as a novel risk factor for endothelial progenitor cell depletion and endothelial dysfunction in systemic lupus erythematosus. Arthritis Rheum 2007, 56:3759-3769.

101. Zhao W, Somers E, McCune WJ, Kaplan MJ: Type I interferon signatures are associated with vascular risk and atherosclerosis in systemic lupus erythematosus. Arthritis Rheum 2009, 59:S582.

102. Yao Y, Richman L, Higgs BW, Morehouse CA, de los Reyes M, Brohawn P, Zhang J, White B, Coyle AJ, Kiener PA, Jallal B: Neutralization of interferonalpha/beta-inducible genes and downstream effect in a phase I trial of an anti-interferon-alpha monoclonal antibody in systemic lupus erythematosus. Arthritis Rheum 2009, 60:1785-1796.

103. McBride JM, Wallace DJ, Yao Z, Morimoto A, Jiang J, Maciuca R, McLean I, Drappa J: Dose-dependent modulation of interferon regulated genes with administration of single and repeat doses of rontalizumab in a phase I, placebo controlled, double blind, dose escalation study in SLE. Arthritis Rheum 2009, 60(Suppl):S775-S776.

104. Mackay F, Schneider P: Cracking the BAFF code. Nat Rev Immunol 2009, 
9:491-502.

105. Mackay F, Woodcock SA, Lawton P, Ambrose C, Baetscher M, Schneider P, Tschopp J, Browning JL: Mice transgenic for BAFF develop lymphocytic disorders along with autoimmune manifestations. J Exp Med 1999, 190:1697-1710.

106. Stohl W, Xu D, Kim KS, Koss MN, Jorgensen TN, Deocharan B, Metzger TE, Bixler SA, Hong YS, Ambrose CM, Mackay F, Morel L, Putterman C, Kotzin BL, Kalled SL: BAFF overexpression and accelerated glomerular disease in mice with an incomplete genetic predisposition to systemic lupus erythematosus. Arthritis Rheum 2005, 52:2080-2091.

107. Jacob CO, Pricop L, Putterman C, Koss MN, Liu Y, Kollaros M, Bixler SA, Ambrose CM, Scott ML, Stohl W: Paucity of clinical disease despite serological autoimmunity and kidney pathology in lupus-prone New Zealand mixed 2328 mice deficient in BAFF. J Immunol 2006 177:2671-2680.

108. Ramanujam M, Bethunaickan R, Huang W, Tao H, Madaio MP, Davidson A: Selective blockade of BAFF for the prevention and treatment of systemic lupus erythematosus nephritis in NZM2410 mice. Arthritis Rheum 2010, 62:1457-1468

109. Jacob N, Guo S, Mathian A, Koss MN, Gindea S, Putterman C, Jacob CO, Stoh $W: B$ cell and BAFF dependence of IFN- $a$-exaggerated disease in systemic lupus erythematosus-prone NZM 2328 mice. J Immunol 2011, 186:4984-4993.

110. StohI W, Looney RJ: B cell depletion therapy in systemic rheumatic diseases: different strokes for different folks? Clin Immunol 2006, 121:1-12.

111. Collins CE, Gavin AL, Migone TS, Hilbert DM, Nemazee D, Stohl W: B lymphocyte stimulator (BLyS) isoforms in systemic lupus erythematosus: disease activity correlates better with blood leukocyte BLyS mRNA levels than with plasma BLyS protein levels. Arthritis Res Ther 2006, 8:R6.

112. Chu VT, Enghard P, Schürer S, Steinhauser G, Rudolph B, Riemekasten G, Berek $C:$ Systemic activation of the immune system induces aberrant BAFF and APRIL expression in B cells in patients with systemic lupus erythematosus. Arthritis Rheum 2009, 60:2083-2093.

113. Lee YH, Ota F, Kim-Howard X, Kaufman KM, Nath SK: APRIL polymorphism and systemic lupus erythematosus (SLE) susceptibility. Rheumatology (Oxford) 2007 46:1274-1276

114. Kawasaki A, Tsuchiya N, Fukazawa T, Hashimoto H, Tokunaga K: Analysis on the association of human BLYS (BAFF, TNFSF13B) polymorphisms with systemic lupus erythematosus and rheumatoid arthritis. Genes Immun 2002, 3:424-429.

115. Baker KP, Edwards BM, Main SH, Choi GH, Wager RE, Halpern WG, Lappin PB, Riccobene T, Abramian D, Sekut L, Sturm B, Poortman C, Minter RR, Dobson CL, Williams E, Carmen S, Smith R, Roschke V, Hilbert DM, Vaughan TJ, Albert VR: Generation and characterization of LymphoStat-B, a human monoclonal antibody that antagonizes the bioactivities of B lymphocyte stimulator. Arthritis Rheum 2003, 48:3253-3265.

116. Furie R, Stohl W, Ginzler EM, Becker M, Mishra N, Chatham W, Merrill JT, Weinstein A, McCune WJ, Zhong J, Cai W, Freimuth W; Belimumab Study Group: Biologic activity and safety of belimumab, a neutralizing anti-Blymphocyte stimulator (BLyS) monoclonal antibody: a phase I trial in patients with systemic lupus erythematosus. Arthritis Res Ther 2008 10:R109.
117. Wallace DJ, StohI W, Furie RA, Lisse JR, McKay JD, Merrill JT, Petri MA, Ginzler EM, Chatham WW, McCune WJ, Fernandez V, Chevrier MR, Zhong ZJ, Freimuth WW: A phase II, randomized, double-blind, placebo-controlled, dose-ranging study of belimumab in patients with active systemic lupus erythematosus. Arthritis Rheum 2009, 61:1168-1178.

118. Furie RA, Petri MA, Wallace DJ, Ginzler EM, Merrill JT, StohI W, Chatham WW, Strand V, Weinstein A, Chevrier MR, Zhong ZJ, Freimuth WW: Novel evidencebased systemic lupus erythematosus responder index. Arthritis Rheum 2009, 61:1143-1151.

119. Navarra S, Guzman R, Gallacher A, Levy RA, Li EK, Thomas M, Jimenez R, Leon M, Hall S, Lan JL, Nasonov E, Tanasescu C, Kim HY, Pineda L, Zhong ZJ, Freimuth W, Petri MA; BLISS-52 Study Group: Belimumab, a BLyS-specific inhibitor, reduced disease activity, flares and prednisone use in patients with active SLE: efficacy and safety results from the phase 3 BLISS-52 study [abstract]. Arthritis Rheum 2009, 60:3859.

120. Furie R, Zamani O, Wallace D, Tegzová D, Petri M, Merrill JT, Chatham W, Stohl W, Schwarting A, Cooper S, Zhong ZJ, Freimuth W, Hough D, van Vollenhoven RF; BLISS-76 Study Group: Belimumab, a BLyS-specific inhibitor, reduced disease activity and severe flares in seropositive SLE patients: BLISS-76 study results through wk 76. Arthritis Rheum 2010; 62:5606.

121. Manzi S, Sanchez-Guerrero J, Merrill JT, Furie RA, Gladman D, Navarra S, Ginzler EM, D'Cruz D, Doria A, Cooper S, Zhong ZJ, Hough D, Freimuth W, Petri M; BLISS-52 and BLISS-76 Study Groups: Belimumab, a BLyS-specific inhibitor, reduced disease activity across multiple organ domains: combined efficacy results from the phase 3 BLISS-52 and -76 studies. Arthritis Rheum 2010, 62:5607.

122. Dall'Era M, Chakravarty E, Wallace D, Genovese M, Weisman M, Kavanaugh A, Kalunian K, Dhar P, Vincent E, Pena-Rossi C, Wofsy D: Reduced B lymphocyte and immunoglobulin levels after atacicept treatment in patients with systemic lupus erythematosus: results of a multicenter, phase lb, doubleblind, placebo-controlled, dose-escalating trial. Arthritis Rheum 2007, 56:4142-4150

123. StohI W, Merrill JT, Looney RJ Buyon J, Wallace DJ, Weisman M, Ginzler EM, Cooke B, Holloway D, Kuchimanchi K, Cheah TC, Rasmussen E, Ferbas J, Belouski SS, Zack DJ: Phase 1a single- and phase 1b multiple-dose studies of AMG 623 (an anti-BAFF peptibody) in systemic lupus erythematosus (SLE). Arthritis Rheum 2008, 58:S565.

124. Stohl W, Hiepe F, Thomas M, Scheinberg M, Clarke A, Aranow C, Jimenez R, Wellborne F, Abud-Mendoza C, Hough D, Pineda L, Migone TS, Freimuth W, Chatham W; BLISS-52 and BLISS-76 Study Groups: Belimumab, a BLySspecific inhibitor, significantly reduced autoantibodies, normalized low complement, and reduced selected B-cell populations in patients with seropositive systemic lupus erythematosus (SLE): the phase 3 BLISS studies. Arthritis Rheum 2010, 62:5480.

125. Kikly K, Manetta J, Smith H, Wierda D, Witcher D: Characterization of LY2127399, a neutralizing antibody for BAFF [abstract]. Arthritis Rheum 2009, 60:693.

doi:10.1186/a3349

Cite this article as: Jacob N, Stohl W: Cytokine disturbances in systemic lupus erythematosus. Arthritis Research \& Therapy 2011, 13:228. 